\title{
Establishing a Hydrographic Framework for Watershed Management across Northern Chile
}

\author{
Gustavo Moran1, Pedro Paolini Cuadra², John-Paul Arp33, Paul A. Arp ${ }^{3 *}$ \\ ${ }^{1}$ Surnorte Inc., Toronto, Canadá \\ ${ }^{2}$ LP Consultores Ltda., Santiago, Chile \\ ${ }^{3}$ Faculty of Forestry \& Environmental Management, Fredericton, Canada \\ Email: *arp1@unb.ca
}

How to cite this paper: Moran, G., Cuadra, P.P., Arp, J.-P. and Arp, P.A. (2018) Establishing a Hydrographic Framework for Watershed Management across Northern Chile. Journal of Geographic Information System, 10, 539-561.

https://doi.org/10.4236/jgis.2018.105029

Received: August 18, 2018

Accepted: October 22, 2018

Published: October 25, 2018

Copyright (C) 2018 by authors and Scientific Research Publishing Inc. This work is licensed under the Creative Commons Attribution International License (CC BY 4.0).

http://creativecommons.org/licenses/by/4.0/

\begin{abstract}
This article demonstrates how currently available digital elevation (NASA SRTM; $30 \mathrm{~m}$ resolution) and hourly global precipitation data (rain, snow; 5 and $10 \mathrm{~km}$ resolution) can be used to hydrographically quantify the regional watershed management context across northern Chile. This is done through comprehensive derivations of flow direction, flow accumulation, flow channels, floodplain extent, depressions, and upslope watershed outlines. In turn, these derivations allow for estimating potential precipitation accumulations within any watershed, and turn these into subsequent storm-averaged discharge estimates at, e.g., at any road-flow-channel crossing points. This article elaborates on this by modelling and mapping hydrological conditions and subsequent storm damage at the regional scale and at select locations in terms of recent flood events on March 2015, May 2017, and June 2017. It was found that modelled flood extent and storm-estimated discharge volumes and rates generally conform to reported values including storm-caused damages within communities along the Huasco, Elqui, Limari, Copiapó and Salado rivers. This included the storm response assessment of six water reservoirs as these varied, as quantified, from normal (Puclaro, La Laguna, Cogoti), at capacity (La Paloma, Cogoli), and overflowing (Recoleta). The details of the local to regional assessments are presented in the form hydrologically explicit maps, figures and tables. Together, these attest to the general validity of the framework as introduced. Hydrometrically based stream-discharge calibrations would assist in further refining the approach, especially in terms of estimating local to regional run-off coefficients.
\end{abstract}

\section{Keywords}

Northern Chile, Watersheds, Precipitation, Digital Elevation Modelling, Hydrographic Interpretations, Storm Events 


\section{Introduction}

Arid conditions combined with occasional heavy rainfall events are leading to catastrophic flashfloods, as have been reported for Northern Chile [1]. For example, on March 25-27, 2015, a 3-day rainfall, amounting to $75 \mathrm{~mm}$, displaced about 30,000 people across the Antofagasta and Atacama regions through mudflow and flooding [2] (Figure 1). This included a rising death toll, more than 8,000 houses damaged or destroyed, extensive road blockages leading to community isolation, compromised water supplies, and temporary suspension of industrial activities. Similar rain events tend to be benign elsewhere. The generally parched and barren soil and bedrock terrain, however, is prone to transform otherwise ordinary rainfall events into valley-focused landslides, flashfloods, and mudflows [3]. An in-depth geophysical analyses of the March 25-27, 2015 flood event [4] [5] focussed on the Salado River watershed and related flash-induced mudflow impacts on the communities along this river, notably Copiapó, Diego de Almagro and Chañaral. It was found that the release of mud was mainly caused by floodplain re-channeling, coupled by flow-retarding debris that accumulated within dry ravines and riverbeds prior to the event [6]. Recent flood events across the Coquimbo province (May 12, 2017) and Antofagasta (June 8, 2017) were also damaging, but not to the same extent.

In view of recurring storm events, Chilean government departments, communities and industries have become increasingly mindful in reviewing community locations, transportation routes, landuse, industrial locations and activities, and placement of hydrological infrastructure [7] [8] [9]. Major industrial activities refer to strip and underground mining, ore and cement processing, and salt mining in water-accumulating depressions (salars [10]). Challenges refer to, e.g. [11] [12] [13]:

1) ensuring socio-economic sustainability;

2) reducing negative impacts on human health;

3) stabilizing access routes (roads, railway tracks, powerlines, pipelines);

4) stabilizing mine tailings, including unconsolidated debris and dust piles;

5) protecting water supplies and communities;

6) reducing soil and sediment contamination;

7) conservingsalar ecologies.

In reference to flood-related damages including mobilizations of contaminants, [14] and [15] commented on benefits, challenges, legal requirements and innovations regarding protecting waterways downslope from active and inactive mines. Primary options deal with dam stabilization, stacking dewatered mine tailings away from watercourses, and advancing towards contaminant-free metal extraction and refinement processes. Afforestation would also play important in terms of soil stabilization and enhancing rural developments [16].

This article focusses on quantifying the hydrographic flow channel, depres- 
sion and watershed context across northern Chile in a locally to regionally comprehensive manner. This was done by way of combining established digital elevation modelling routines with NASA's globally available precipitation distribution data in order to estimate amounts of water received and flowing across storm-impacted watersheds. In reference to storm-impacted accounts and analyses, emphasis is on building a comprehensive overview on where and how much water could potentially flow towards and through communities across northern Chile for any particular precipitation event.

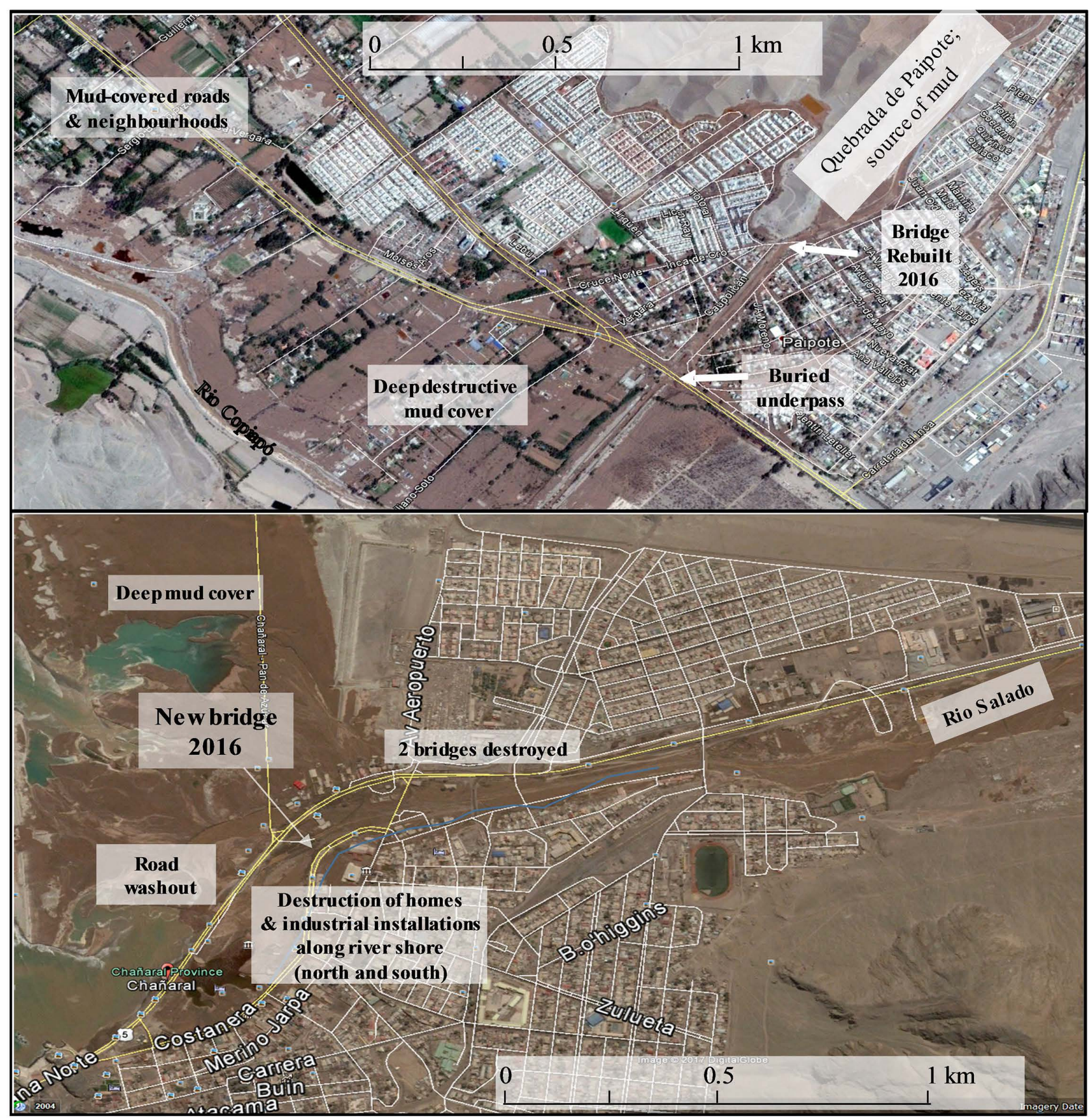

Figure 1. Extent of flood-caused mud coverage centered on Copiapó (top) and Chañaral (bottom) following the March 2015 flashflood events within the Atacama province, of northern Chile. Background: Google Earth images, April 2015. 


\section{Methods}

The Northern Chile precipitation events for March 25-27, 2015 and May 12, 2017 were captured for the Arica, Tarapacá, Antofagasta, Atacama and Coquimbo regions using NASA's georeferenced NEX-GDD Precipitation [17] and GPM [18] rain and snow data layers. These data were re-projected (utm 19s) and re-interpolated to match NASA's SRTM digital elevation coverage (30 m resolution) [19] across the regions. This data capture was extended beyond Chile's borders to ensure complete cross-border watershed coverages to assess the total amounts of precipitation received per watershed and per duration of storm event.

The re-projected digital elevation model (DEM) served to delineate local to regional flow networks using the D8 algorithm to determine flow direction and flow accumulation from the filled DEM [20]. Doing so established the flow direction rasters and the resulting pixel-specific flow-accumulation pattern.

Depressions were located by subtracting the non-filled DEM from the filled DEM. All depressions with significant water retention capacity up to their pour points were mapped by extent, depth, volume, and upslope watershed areas. The DEM-derived flow-channel networks were obtaining from the flow-accumulation raster by setting upstream flow-accumulation thresholds at $40,400,4000$ and 40,000 ha, followed by raster to polyline conversion. This was done to emulate the extent to which the flow networks would advance towards or retract from higher elevations towards depressions and the coast by season and climate.

The extent of depression-terminated flow channels was emulated stepwise using increasing water-retaining volume capacity thresholds from $0.1 \mathrm{ML}$ to $10 \mathrm{GL}\left(1 \mathrm{ML}=10^{3} \mathrm{~m}^{3} ; 1 \mathrm{GL}=10^{6} \mathrm{~m}^{3}\right)$ in order of magnitude steps. The capacity of the depressions to retain water was estimated by summing the $30 \mathrm{~m}$ $\times 30 \mathrm{~m}$ pixel depths across each depression. Flow channels were set to terminate at the lowest point in depression unless ready to overflow at the depression outlets.

The maximum amount of water potentially flowing along the DEM-derived flow channels was estimated by assigning the raster-based NASA-precipitation or rain amounts to each DEM raster cell, and summing these amounts along each flow accumulation path towards each water-receiving depression including the Pacific Ocean. The resulting sum was corrected by the amount of water retained within each upslope depression. The sum of water so accumulating was divided by storm duration to estimate the storm-average flow rates per event in $\mathrm{m}^{3} \cdot \mathrm{sec}^{-1}$.

In principle, the numbers should serve as first-approximation location and event-specific flow-severity metrics. Hydrometric adjustments would be needed to account for, e.g., run-off diminishing evapotranspiration losses, snow sublimation, and soil and groundwater storage. Further adjustments may be required to account for actual amounts of water retained by upstream water reservoirs 
prior to each storm event, because SRTM-captured reservoir elevations are specific to the year of SRTM-DEM data capture $(\approx 2000)$.

The extent of soil moisture regime and floodplain zonations next to the DEM-derived flow channels was determined using the cartographic depth-to-water (DTW) algorithm [21] [22] [23] (Figure 2). Floodplain extent was mapped by requiring 400 ha of upslope flow accumulation for floodplain initiation. The floodplains so mapped can be used to estimate:

1) Potential flood extents and related risks to settlements and infrastructure, especially where DTW $<1 \mathrm{~m}$;

2) Extent of arable land and related hydric to xeric soil moisture regimes, by climate regime and elevation; in general, the hydric to xeric elevation decreases from the Coquimbo region northward, with increasing elevation, and with decreasing flow accumulation. For example, the extent of arable land along most flow channels at elevations $<2000 \mathrm{~m}$ from Copiapó southwards extends up to about $40 \mathrm{~m}$ above the main floodplain channels. Further north, flow channels and floodplains remain mostly arid unless subject to storm events. During those events, flood heights were found to reach up to DTW = $8 \mathrm{~m}$ (see below).

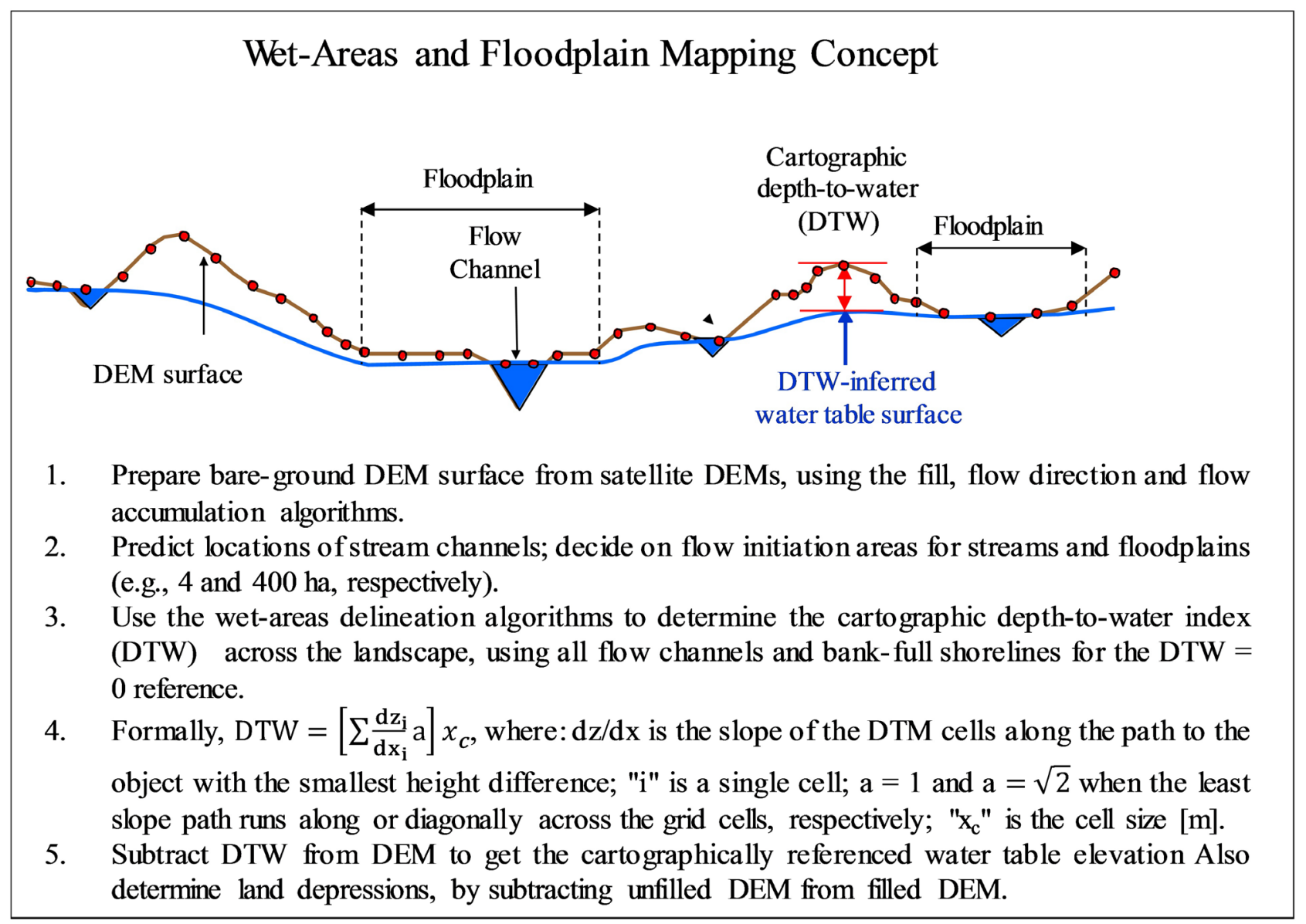

Figure 2. Wet-areas and floodplain mapping concept. 
Other datalayers (shapefiles) relevant for establishing hydrographic context were obtained from the internet, i.e., Open Street Map (OSM) for roads and streams [24], Map Cruzing [25] for places and landuse, DIVA-GIS [26] for administrative borders, roads, water and watercourse features, List of Saltpeter Works in Tarapacá and Antofagasta [27], and Mine Search [28]. Mining locations were also located based on latest available Google Earth satellite imagery (2014-2016) by placemarking each location while referring to open-pit and underground mines, ore-processing, and tailing ponds.

The flowchart in Figure 3 presents the framework by which NASA-compiled precipitation layers were combined with STRM-generated DEM layers to determine 1) how much water was received within each DEM pixel, and 2) the extent to which these amounts accumulated along the DEM-determined depression and flow accumulation patterns. The resulting depression-overflow pattern was used to develop the regional to local flow networks. These varied by storm event from terminating in non-overflowing depressions (hence endorheic) or reaching the Pacific shore (hence exorheic). Open Street delineations were used to automatically 1) locate all road-stream intersection points and their upstream flow-retaining and -accumulating watershed areas, and 2) determine total storm flow volumes and storm-averaged discharge rates. The slope and flow-channel generated DTW derivations were used to delineate flood and soil moisture regime extent zonations above water-containing flow channels and water bodies. The entire framework was developed and coded for seamless ArcGIS processing, with special attention given to terminating flow channels in non-overflowing depressions. All input and output data layers were assembled in the form of an ArcMap package, and were used to produce the maps shown below.



Figure 3. Hydrographic framework for watershed management for storm-based water flow, retention, and flood extent estimation using local to regional DEM-generated flow channel and depression delineations with emphasis on road-stream crossings. 


\section{Results and Discussion}

Table 1 lists major cities and towns where major flood damage may or may not have occurred for the March 2015 and the May and June 2017 storm events. Also specified are:

1) upslope basin areas (in $\mathrm{km}^{2}$ );

2) percent of floodplain coverage within upslope basins;

3) amount of precipitation (snow, rain) received per upslope basin as derived from NASA's precipitation rasters;

4) corresponding estimate for average flow rates per storm duration by locations, assuming no water retention or loss per storm duration.

\section{March 2015 Flood Event, Northern Chile}

Presented in Figure 4 is an overview of the data layers used for establishing the hydrographic flash-flood context for the four northern regions in Chile pertaining to the 25-27 March 2015 precipitation (rain) event. Shown are: 1) the NASA captured precipitation pattern; 2) the DEM-derived delineation of watersheds receiving significant amounts of precipitation; 3) the SRTM-captured variation in elevation (hill-shaded) 4) the distribution of water-retaining

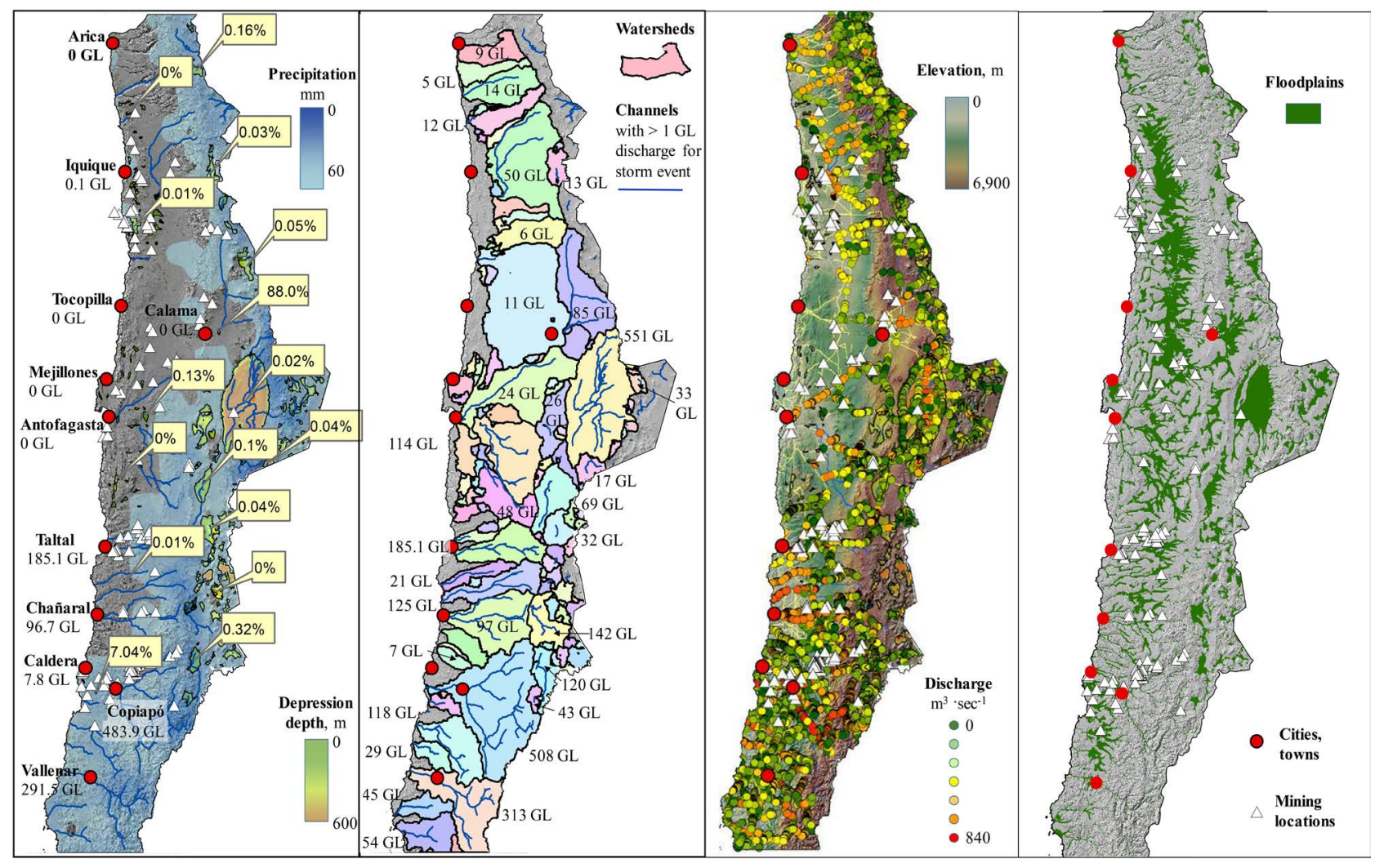

Figure 4. Northern Chile (Arica, Tarapaca, Antofagasta, and Atacama regions). A: Cities and towns in relation to NASA projected precipitation amount (March 25-27, 2015), also showing estimated volume of water received in GL and percent fill of DEM-derived depressions. B: Watershed basins with received rainfall amounts (in GL). C: Estimated stream and river discharge rates (in $\mathrm{m}^{3} \cdot \mathrm{sec}^{-1}$; water only, mud excluded) along roads assuming runoff with no evapotranspiration and upslope soil-water storage other than in depressions. D: DEM-derived floodplain extent, up to $40 \mathrm{~m}$ in elevation from floodplain flow channels. Also shown in C and D: mining locations (white triangles). Back-ground: hill-shaded STRM DEM (30 m resolution). 

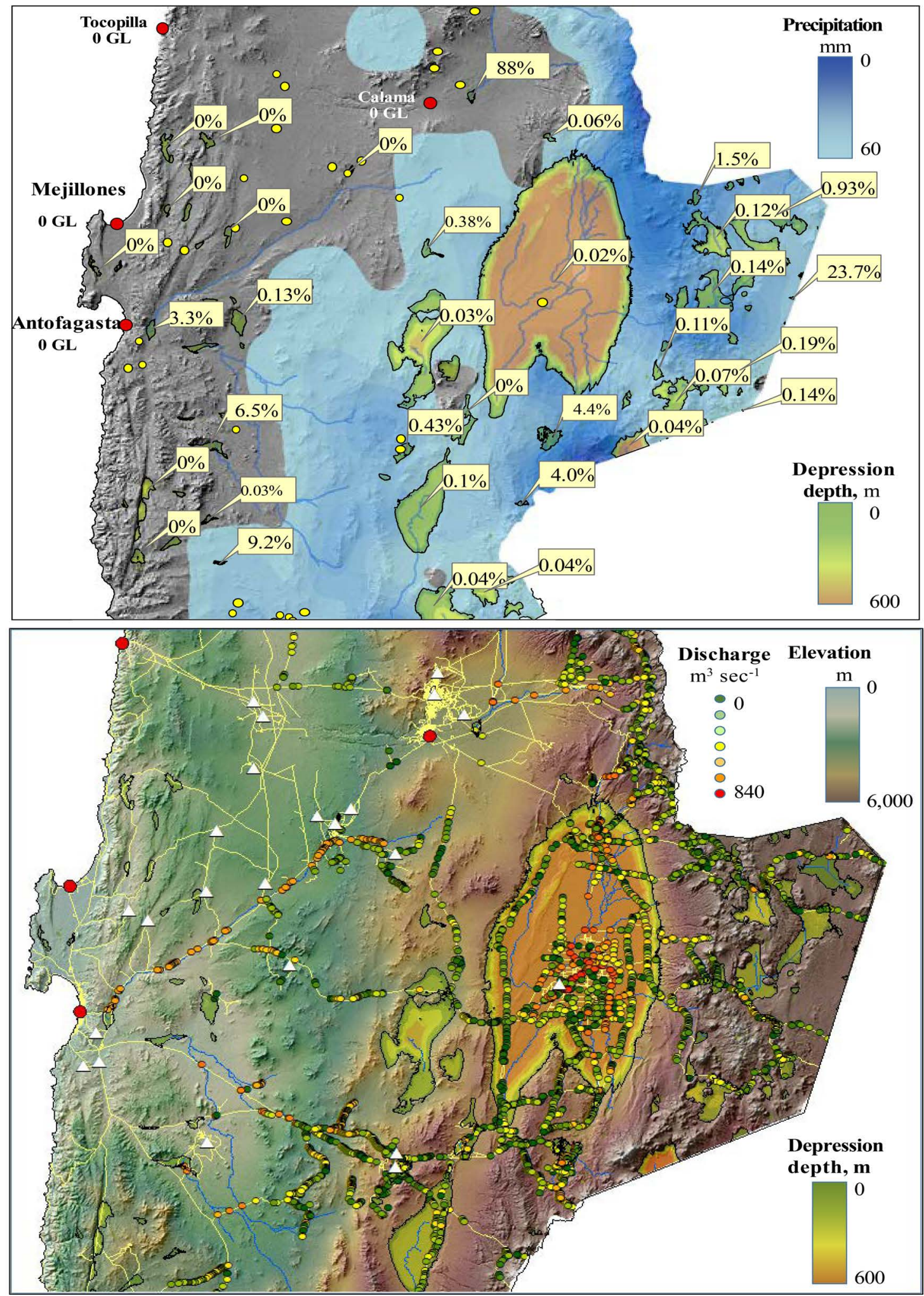

Figure 5. Close ups of Figure $4 \mathrm{~A}$ and $\mathrm{C}$ for the March 25-27, 2015 storm event, with focus on salar forming depressions by extent and depth, and the SRTM-DEM derived maximum endorheic stream-flow pattern overlain on hill-shaded DEM. Top: NASA-derived precipitation pattern, together with the percent extent to which the depressions would have filled. Bottom: potential maximum storm discharge flow rates (mud content excluded) in $\mathrm{m}^{3} \cdot \mathrm{sec}^{-1}$ along roads, assuming runoff with no evapotranpiration and upslope soil-water storage other than in the depressions. 

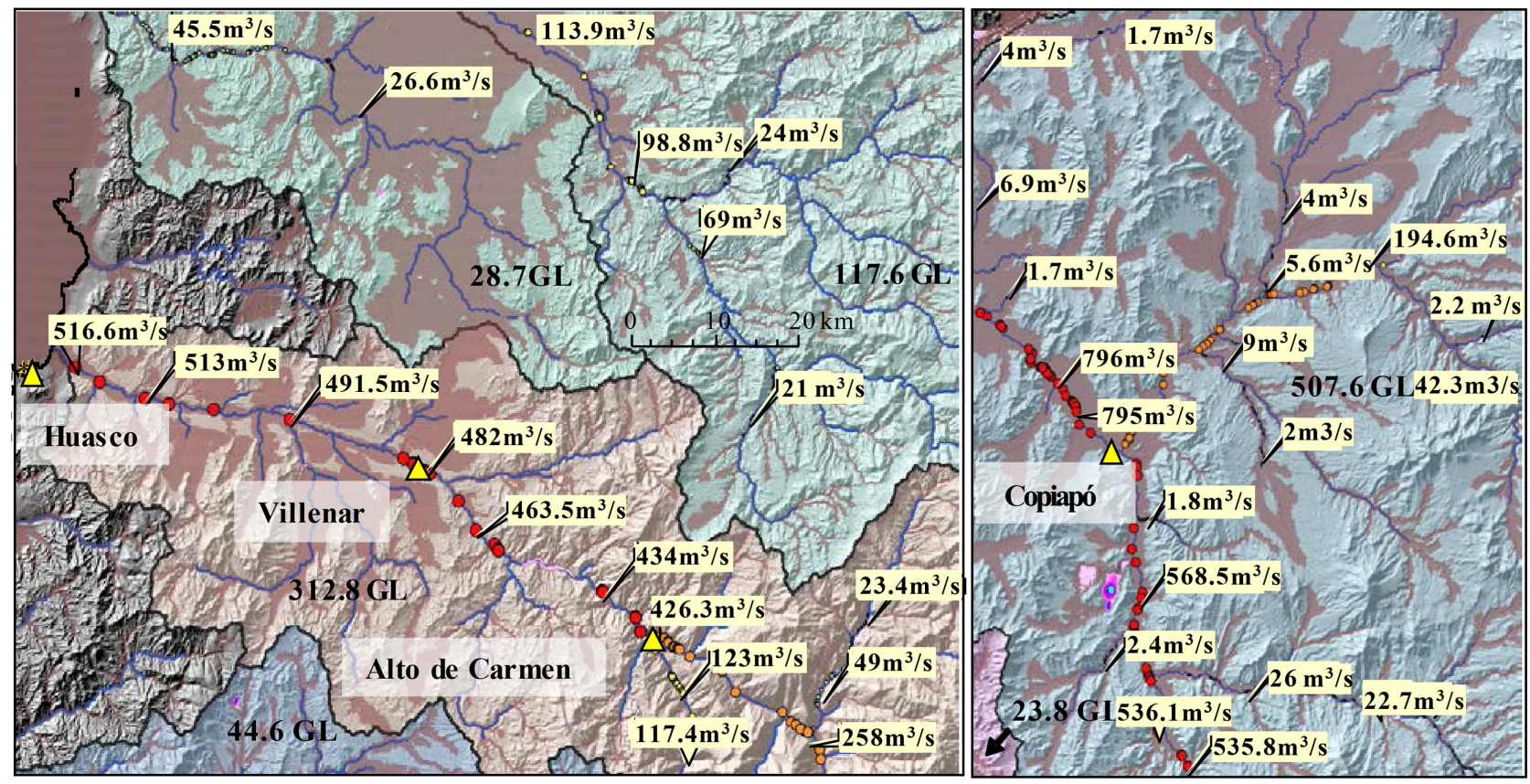

Figure 6. Close-ups of watershed (black outlines) and floodplain (brown; extent up to $40 \mathrm{~m}$ above flow plain flow channels) in Figure $4 \mathrm{D}$ depicting DEM and storm-estimated flow rates in $\mathrm{m}^{3} \cdot \mathrm{sec}^{-1}$ (water only, mud excluded) along rivers and streams for the March 25-27, 2015 flood event above Huasco, Villenar, Alto de Carmen (left) and Copiapó (right). These estimates assume no flow rate reductions due to evapotranspiration and soil-water storage other than in depressions. Also shown: amount of rain received per watershed, in GL (bold black numbers).
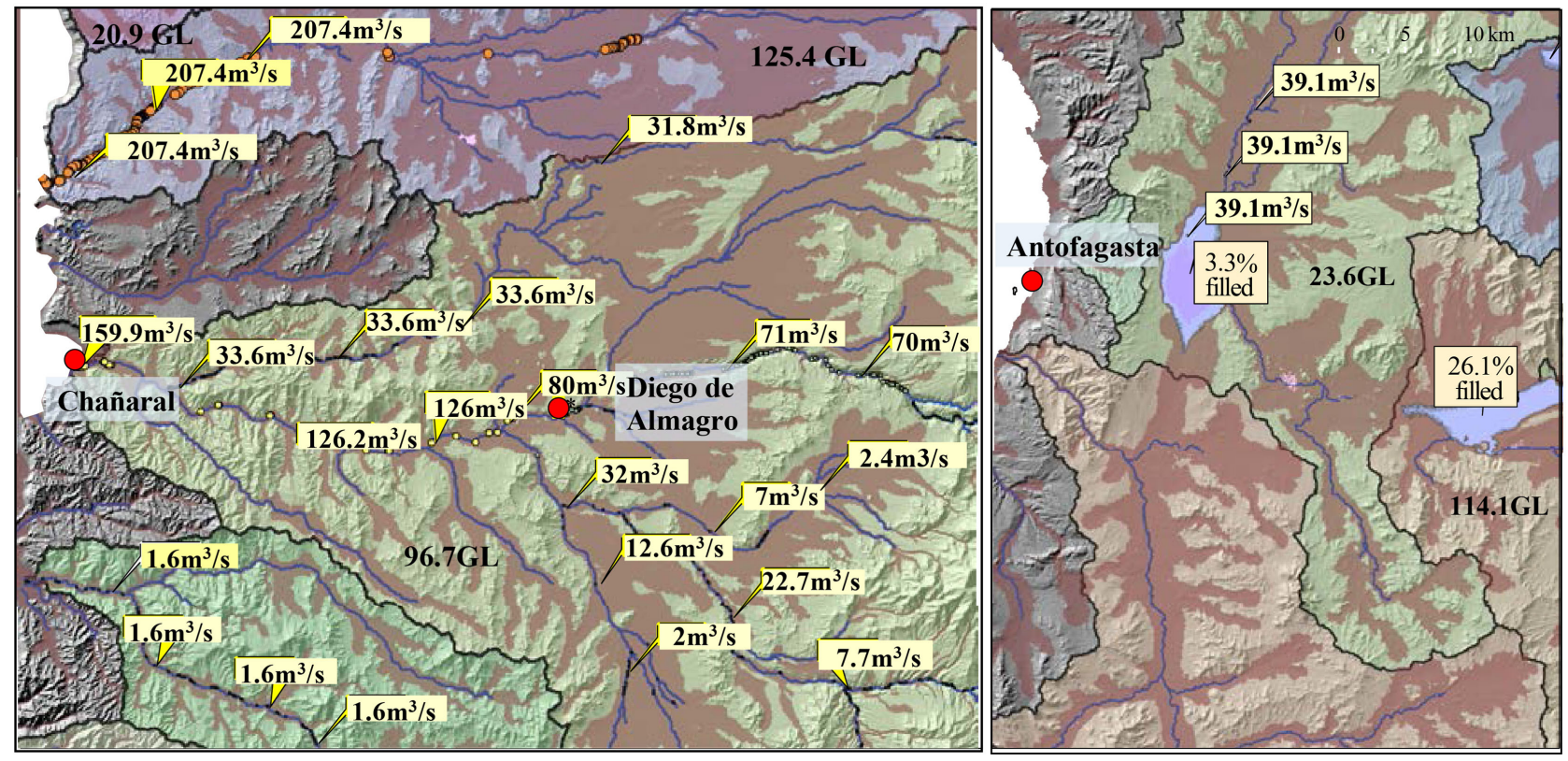

Figure 7. Close-ups of watershed (black outlines) and floodplain (brown; extent up to $40 \mathrm{~m}$ above flow plain flow channels) in Figure $4 \mathrm{D}$ depicting DEM and storm-estimated flow rates in $\mathrm{m}^{3} \cdot \mathrm{sec}^{-1}$ (water only, mud excluded) along rivers and streams above Chañaral, Diego el Almagro (left) and Antofagasta (right) for the March 25-27, 2015 flood event. These estimates assume no significant flow rate reductions due to evapotranspiration and soil water storage other than in depressions. Also shown: amount of rain received per watershed in GL (bold black numbers); two salars east of Antofagasta, with estimated \% of potential storm-based water fill assuming no evapotranspiration and soil infiltration. 
depressions; 5) the locations of cities, towns, and mining activities. Note that the precipitation rates for this event were highest at elevations at $>2000 \mathrm{~m}$, while coastal areas received no to little precipitation.

Some of the water-retaining depressions across Northern Chile are presented in Figure 5 (top) for the March 2015 event. The volume capacities of the larger depressions are displayed in GL, together with the percentage to which these depressions would have been filled. Basins within areas that received $<1 \mathrm{GL}$ of precipitation are not presented. The DEM-derived floodplain pattern is displayed on the far right, with the brown-shaded areas starting below at least 400 ha of upslope flow accumulation area for floodplain initiation, and reaching $40 \mathrm{~m}$ upwards away from the floodplain-defining flow channels to include floodplain terraces, and the extent of foot-slope seepage areas.

Due to prevailingly arid climate conditions, most of the flow channel networks across northern Chile are endorheic. Rio Loa, however, is exorheic due to its deeply incised groundwater-receiving flow channel. Elsewhere, flow channels

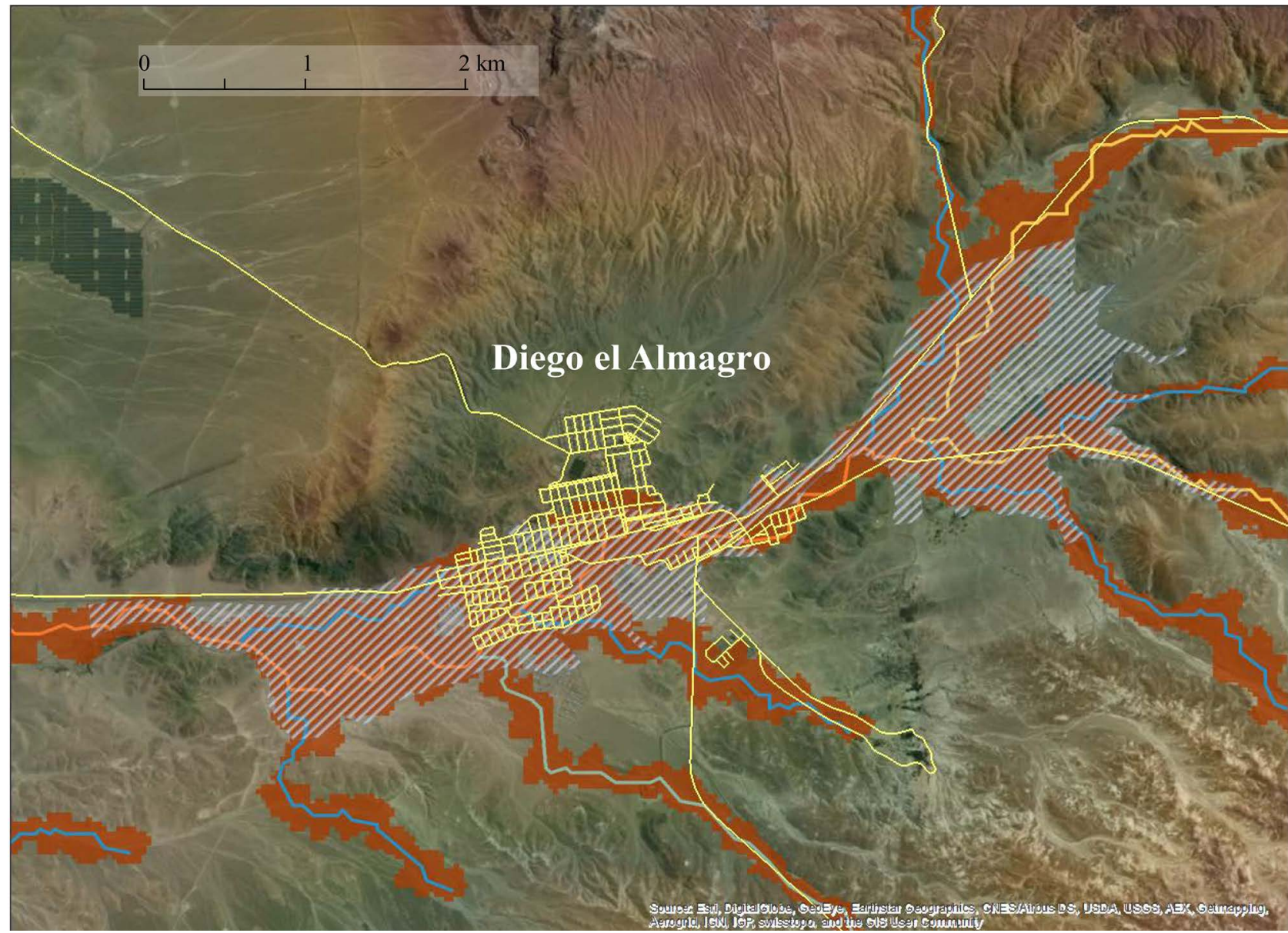

Figure 8. Comparing the observed March 2015 flood extent at Diego el Almagro (hatched area) [28] with the SRTM-DEM derived floodplain map (brown), assuming that the upslope contributing area for floodplain initiation amounts to 400 ha, and that the flood rose $4 \mathrm{~m}$ above the DEM-derived Rio Salado flow channel network (blue lines). Yellow lines: roads (Open Street). Background: Google Earth image. 
terminate in salars, among which the depression at San Pedro de Atacama is the largest across the region, estimated to fill its 3255 GL capacity by only $0.16 \%$ during the March 2015 event.

Figures 6-9 provide close-ups of the DEM-derived flow-channel and floodplain delineations for the areas around Alto de Carmen, Vallenar, Freirina, Copiapo, Diego el Almagro, Chanaral and Antofagasta, with average discharge estimates at select road-stream/river crossings. For Alto de Carmen, Vallenar and Freirina along Rio Huasco, floodwaters would have risen quickly along the low-lying portions of the floodplains owing to steep adjacent basin terrain (Figure 6, left). Reported damages mainly referred to road washouts, landslides, and temporary water contamination. The city of Huasco remained unscathed due to its coastal location outside the Rio Huasco flood-plain.

At Copiapó, the devastating mud-carrying flashflood (Figure 1; Figure 6, right) was likely triggered by debris-built-up mudflow along the dried-out Paipote ravine [6]. This mudflow combined with Rio Copiapó run-off at the same time. As a result, roads, houses, and infrastructure across and adjacent to the main flow channels were torn apart and swept away. Deep mud deposits, up to 2 $\mathrm{m}$ and possibly containing mining-generated contaminants [29], were left along the lower lying portions along the northern section of floodplain. The estimated 51-hr averaged water-only flow rates amounted to 219.1 and $570.8 \mathrm{~m}^{3} \cdot \mathrm{sec}^{-1}$ for the main Paipote and Copiapo flow channels, respectively (Table 1).

Further north at Chanaral, at the mouth of Rio Salado (Figure 7, left), a similar debris-constrained and mud-filled flashflood caused catastrophic damage. According to [4], flow rates peaked at about $1450 \mathrm{~m}^{3} \cdot \mathrm{sec}^{-1}$, with $1150 \mathrm{~m}^{3} \cdot \mathrm{sec}^{-1}$ for water only. Table 1 estimates for the average water-only flow rate during the 51
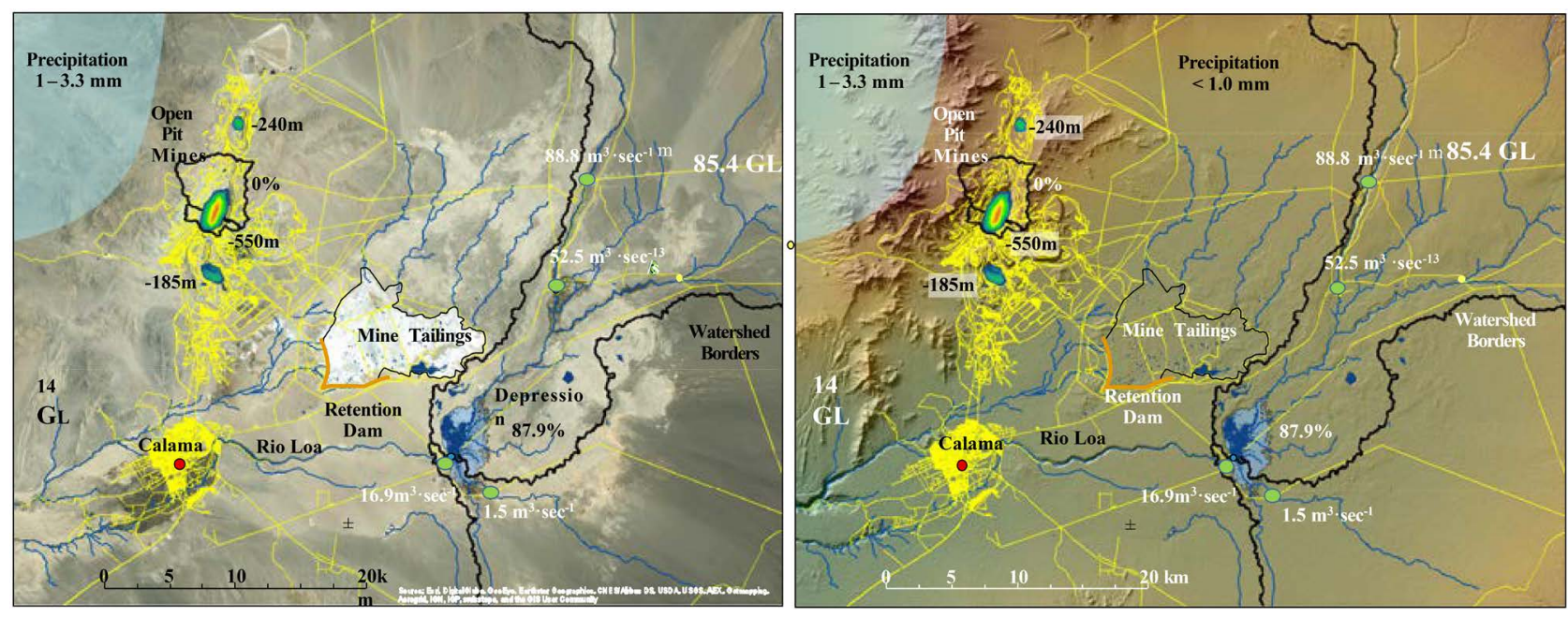

Figure 9. March 20-26, 2015 close-ups for Calama, with Google Earth imagery (left, current) and hill-shaded SRTM DEM (right, year 2000) serving as background, featuring: 1) Open pit mines with pit depth (bold black numbers). 2) Watershed borders (black lines) with amounts of rain received (in GL). 3) Streams (blue lines) and stream discharge rates in $\mathrm{m}^{3} \cdot \mathrm{sec}^{-1}$ (water only, mud excluded) at select locations assuming no evapotranspiration and soil infiltration. 4) Extent of mine tailings retention dam (brown line) below salt-covered pond. 5) The depression east of Calama that would have filled up to $87.9 \%$ if blocked. Yellow lines: roads (Open Street). 
hour event duration is $159.9 \mathrm{~m}^{3} \cdot \mathrm{sec}^{-1}$, i.e. about one tenth of the peak flow rate estimate in [4]. For Diego de Almagro (Figure 7, left), mud-produced damage was also devastating, with an estimated peak flow rate at $310 \mathrm{~m}^{3} \cdot \sec ^{-1}[4]$, while the storm-averaged water-only flow rate in Table 1 amounted to $75 \mathrm{~m}^{3} \cdot \mathrm{sec}^{-1}$. These large differences between peak and storm-averaged flow rates are undoubtedly due to flow-retarding debris at the head of the floods at these locations [6], and at Copiapó as well.

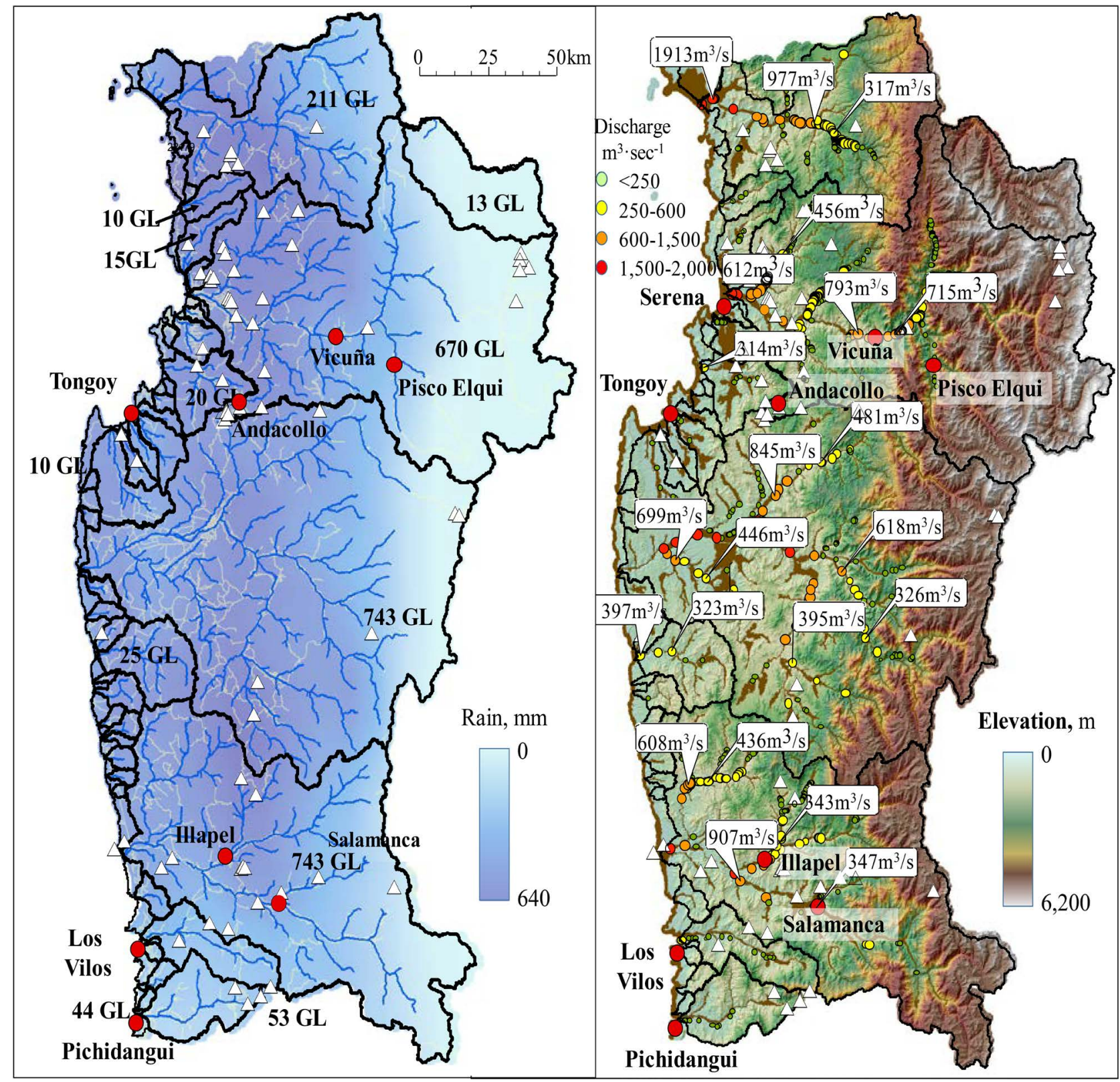

Figure 10. Coquimbo region, May 12, 2017 storm event. Left: NASA-derived precipitation pattern (rain only), with estimated rain amount per watershed (black outlines, in GL), also showing stream network carrying > 10 GL of the incoming rain overlaid on road network (yellow lines). Right: DEM and rain-derived stream discharge rates (24-hour storm average assuming no evapotranspiration or soil based infiltration, in $\mathrm{m}^{3} \cdot \mathrm{sec}^{-1}$ (water only, mud excluded) at select locations along flow channels, overlaid on floodplain extent (colored brown, up to $40 \mathrm{~m}$ elevation away from floodplain channels) and hill-shaded SRTM DEM. 


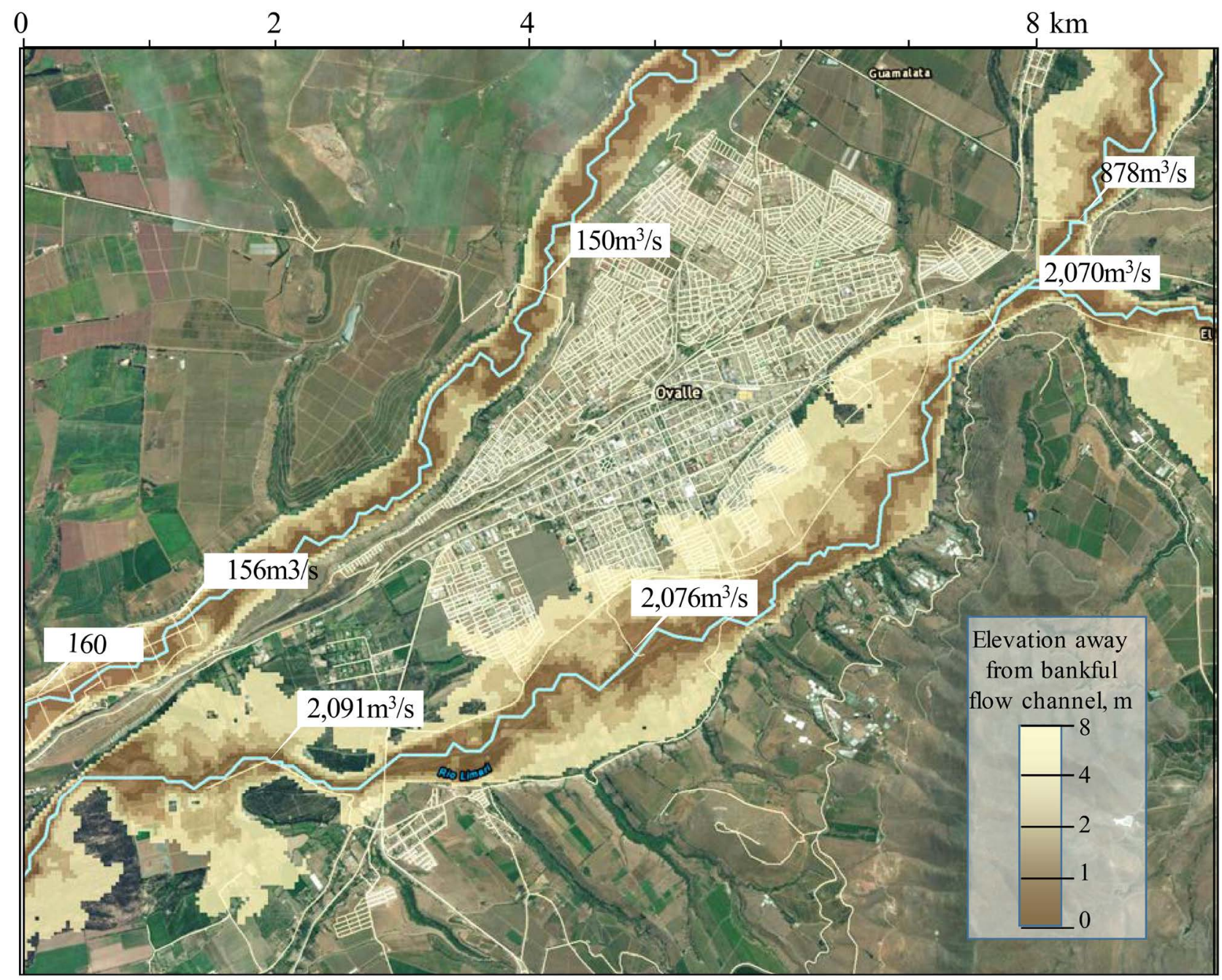

Figure 11. SRTM-DEM estimated potential flood extent centered on Ovalle, up to $8 \mathrm{~m}$ (colored dark brown to beige) above bankful floodplain flow channels, with estimated storm-specific river/stream discharge rates at select locations (24-hour average, in $\mathrm{m}^{3} \cdot \mathrm{sec}^{-1}$; water only, mud excluded), assuming no evapotranspiration and soil-based infiltration. Overlain: Open Street roads (lines). Actual flow rates may have been lower. Background: Google Earth image.

The observed flood extent at Diego de Almagro [30] is overlain on the SRTM-DEM derived flood extent in Figure 8, showing general but not exact agreements. Using a higher-resolution DEM such as bare-earth LiDAR DEMs at $1 \mathrm{~m}$ resolution instead of the $30 \mathrm{~m}$ SRTM DEM would further improve these agreements.

The coastal area around the city of Antofagasta (Figure 7, right) was not affected by the March 2015 rain event, in part due to lack of precipitation along the coastal mountain ridge (Figure 4), and in part due to the water-retaining depressions east and south of the coastal ridge (Figure 5). Similarly, the town of Calama northeast of Antofagasta received little to no precipitation during the March 2015 event (Figure 4 and Figure 5, Figure 9). However, the Rio Loa and its Rio Salado basins received 85.4 GL of precipitation over the course of the 51-hour event (Table 1, Figure 5) due to precipitation interception along the rising Andes mountain ranges east to northeast of Calama. This could have led 
to an average flashflood flow rate of $300.1 \mathrm{~m}^{3} \cdot \mathrm{sec}^{-1}$ at Calama (Table 1). This, however, did not happen as could be inferred from the February 2001 flood analysis for Calama [31] [32] [33]. According to this analysis, much of the water

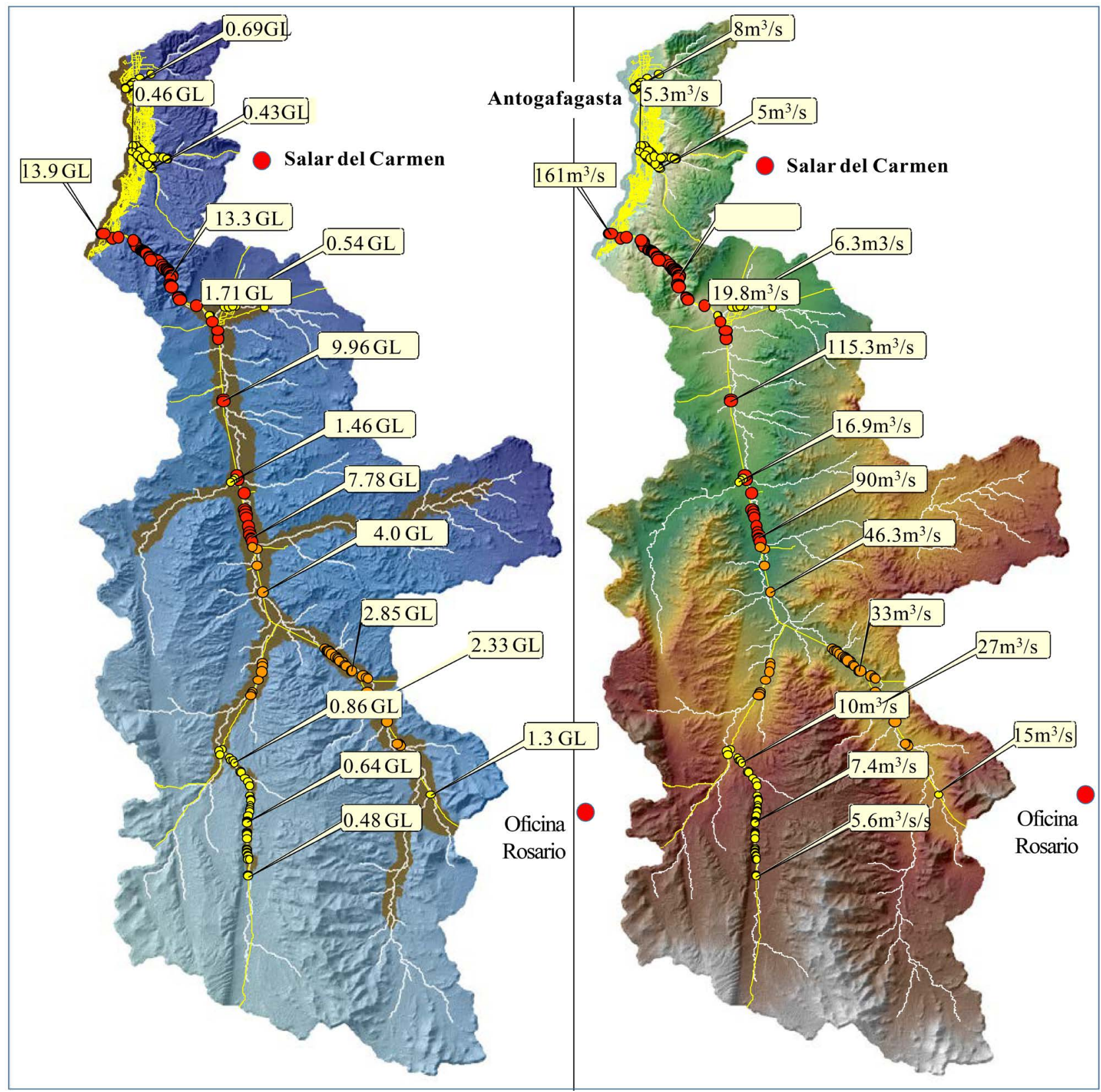

Figure 12. DEM-delineated water-contributing watershed areas (hill-shaded) towards Antofagasta pertaining to the NASA captured June 8, 2017 storm event, assuming that only SRTM-DEM derived depressions $\geq 0.1$ ML retain water. Left: precipitation, flow channels (white) and floodplains (brown; includes areas with DTW $\leq 40 \mathrm{~m}$ above flow channels when bankful), with storm-based flow amounts in GL at select locations. Right: elevation pattern with storm-specific flow rates in $\mathrm{m}^{3} \cdot \mathrm{sec}^{-1}$ (water only, mud excluded) averaged over the storm event. Due to persistently arid conditions, combined water retention and loss due to evapotranspiration and soil infiltration likely would have been at or near $100 \%$ along the south-to-north stretching watershed, but not so along the northern part, where stormwater flows downward along steep flow channels into the coastal floodplain. Yellow lines: Open Street roads. 


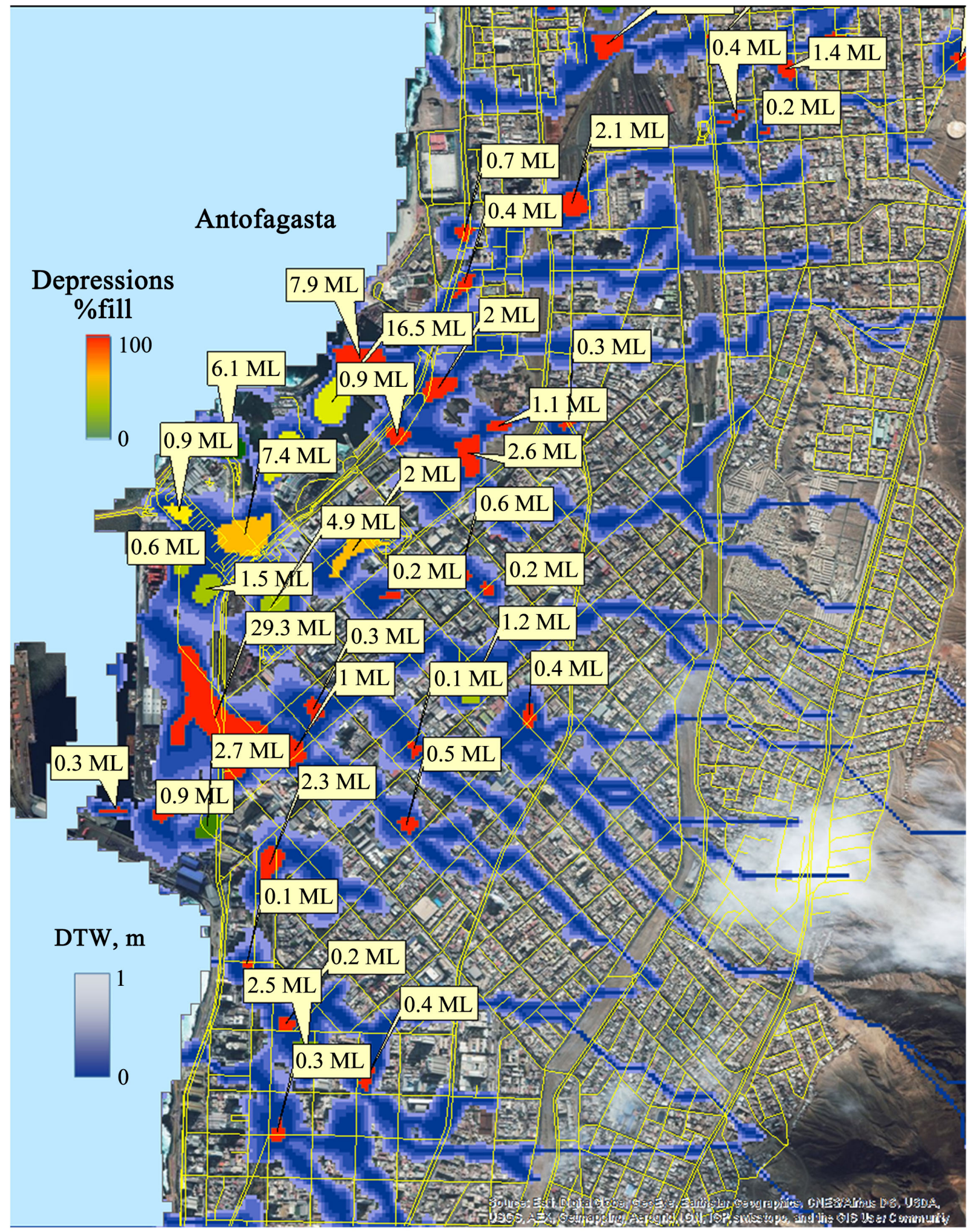

Figure 13. Antofagasta: quantifying the June 2017 flooding extent within the context of the SRTM-DEM derived depressions, with depression volumes in ML and flow channels with their associated DTW $<1 \mathrm{~m}$ delineations. Yellow lines: roads (Open Street). Background: Google earth image. 
Table 1. Hydrographical assessment of upslope basin areas, including floodplain extent, precipitation (rain + snow) received, and storm-averaged flow rates (mud excluded) by location (cities/towns), assuming no water loss and retention during each storm event except for snow accumulation in the Andes.

\begin{tabular}{|c|c|c|c|c|c|c|c|c|}
\hline \multirow[t]{2}{*}{ Event } & \multirow[t]{2}{*}{ Region } & \multirow[t]{2}{*}{ City/Town } & \multirow[t]{2}{*}{ River/Stream } & $\begin{array}{l}\text { Upslope } \\
\text { basin } \\
\text { area }\end{array}$ & $\begin{array}{l}\text { Floodplain } \\
\text { extent per } \\
\text { basin }\end{array}$ & $\begin{array}{c}\text { Upslope } \\
\text { precipitation }\end{array}$ & $\begin{array}{l}\text { Upslope } \\
\text { rain }\end{array}$ & $\begin{array}{c}\text { Average flow } \\
\text { rate }^{*}\end{array}$ \\
\hline & & & & $\mathrm{km}^{2}$ & $\%$ & \multicolumn{2}{|c|}{$10^{6} \mathrm{~m}^{3}(\mathrm{GL})$} & $\mathrm{m}^{3} \mathrm{sec}^{-1}$ \\
\hline \multirow{10}{*}{$\begin{array}{l}\text { 24-26 March 2015: } \\
3 \text { major discharge } \\
\text { peaks within } 51 \text { hrs } \\
\text { across basin areas }\end{array}$} & \multirow{2}{*}{ Antofagasta } & Calama & Rio Lao & 8602 & 5.50 & 85.4 & & 300.1 \\
\hline & & Taltal & Quebrada del Taltal & 5517 & 5.20 & 185.1 & & 306.1 \\
\hline & \multirow{4}{*}{ Atacama } & Chanaral & Quebrada del Salado & 8390 & 3.52 & 97.7 & & 159.9 \\
\hline & & Diego de Almagro & Quebrada del Salado & 2393 & 2.86 & 45.4 & & 75 \\
\hline & & Paipote & Quebrada de Paipote & 6660 & 1.86 & 132.5 & & 219.1 \\
\hline & & Copiapo & Rio Copiapo & 17018 & 0.71 & 345.2 & & 570.8 \\
\hline & \multirow{4}{*}{ Coquimbo } & Freirina & Rio Huasco & 9499 & 1.22 & 310.0 & & 512.5 \\
\hline & & Vallenar & Rio Huasco & 9438 & 0.70 & 291.5 & & 482 \\
\hline & & Alto del Carmen & Rio Del Carmen & 3038 & 0.57 & 75.8 & & 125.4 \\
\hline & & Alto del Carmen & Rio Huasco & 4105 & 0.85 & 177.3 & & 293.2 \\
\hline \multirow{6}{*}{$\begin{array}{c}12 \text { May 2017: } \\
1 \text { major discharge } \\
\text { peak within } 24 \text { hrs } \\
\text { across basin areas }\end{array}$} & \multirow{6}{*}{ Coquimbo } & Pisco Elqui & & 21.7 & 0.50 & 2.4 & 0.6 & 7.0 \\
\hline & & Vicuna & Rio Elqui & 5946 & 0.88 & 442.6 & 61.4 & 710.3 \\
\hline & & La Serena & Rio Elqui & 9407 & 1.14 & 670.2 & 223.7 & 2589.0 \\
\hline & & Ovalle & Rio Limari & 9357 & 1.35 & 972.8 & 308.0 & 3565.3 \\
\hline & & Salamanca & Rio Chopa & 2234 & 1.14 & 249.8 & 27.3 & 315.6 \\
\hline & & Illapel & Rio Illapel & 1913 & 1.14 & 197.7 & 71.8 & 830.5 \\
\hline \multirow{2}{*}{$\begin{array}{l}8 \text { June 2017: } \\
1 \text { major discharge } \\
\text { peak over } 24 \text { hrs } \\
\text { across basin areas }\end{array}$} & \multirow[b]{2}{*}{ Antofagasta } & Antofagasta & Quebrada Caracoles & 40.5 & 1.68 & 1.0 & & 11.0 \\
\hline & & Antofagasta & Quebrada La Negra & 2106 & 3.26 & 52.7 & & 585.0 \\
\hline
\end{tabular}

${ }^{* *}$ Average flow rate, assuming that upslope precipitation amount is discharged (no soil storage, no evapotranspiration) during the 51 or 24 yr event durations. Peak flow rates could be twice as high, approximately, as estimated fer Chanaral (Wilcox et al. 2016).

falling into the Rio Loa and Rio Salado basins above Calama would have entered groundwater reservoirs, with groundwater levels at Calama gradually rising about 2 to 3 months after the event [34]. Prorating the 2015 in terms of the 2001 flood event suggests that the 2015 groundwater level (GWL) at Calama could have risen by $92 \mathrm{~cm}$, as follows:

$$
G W L_{\text {rise }}(2015)=G W L_{\text {rise }}(2001) \times V_{p p t}(2015) / V_{p p t}(2001) \text {, }
$$

where $G W L_{\text {rise }}(2001)=34 \mathrm{~cm}, V_{p p t}(2001)=31.6 \mathrm{GL}$, and $V_{p p t}(2015)=85.6 \mathrm{GL}$ (from Table 1). The reason that Calama did not flood in 2015 but did so in 2001 relates to the fact that the February 2001 storm event was centered on the Ata- 
cama desert, and this included Calama and the steep terrain north and northeast of the Chuquicamata open pit mines [33].

Of special note is the SRTM-DEM mapped depression above the Rio Loa gorge east of Calama (Figure 9). This DEM-generated depression is likely artificial due to geospatial $30 \mathrm{~m}$ grid-point interpolation across steep terrain and particularly so across the entrance point (pour point) of this gorge. Due to this artifact, the depression could have filled up to $86 \%$ of its estimated water-holding capacity. Inspecting the surface images provides evidence that water-filled and salt-enriched depressions exist in this area as mapped in Figure 9.

\section{May 2017 Flood Event: Coquimbo Region}

The Atacama and Coquimbo regions were again affected by heavy rains on May 12, 2017, causing loss of life, substantial damage to homes and roads, community isolation, and flood-compromised water supplies. The NASA-captured GPM rain- and snow-precipitation pattern, depicted for rain $\mathrm{mm}$ in Figure 10 (left), enveloped the entire Coquimbo region for about 8 hours, with La Serena, Vicuna, Ovalle, Illapel and Salamanca along Rio Elqui, Rio Limari and Rio Choapa subject to fast rising floodwaters. Within the Atacama region to the north, Freirina, Alto de Carmen, Villenar, Chañaral and Diego de Almagro also received torrential flows, while the Huasco and Chañaral harbors were partially to completely closed to ship traffic.

The estimated maximum average discharge rates set in Table 1 for rain-induced storm discharge duration without upslope water retention amounted to 2589 and $3565 \mathrm{~m}^{3} \cdot \mathrm{sec}^{-1}$ at La Serena and Ovalle, respectively. Accounting for upslope water retention dropped the flow rate estimates in Table 2 to 1752 and 2089 $\mathrm{m}^{3} \cdot \mathrm{sec}^{-1}$, respectively. At Ovalle, however, flooding damage was extensive by reaching into residential areas as reported and mapped in Figure 11. In contrast, the bridges across Rio Elqui at La Serena (May 19, 2017) had sufficient capacity to accommodate the May 12, 2017 flood event: the post-flood image on Google Earth (May 19, 2017; Figure 11) indicates no infrastructure or housing damages at La Serena, while re-channelization occurred within the Rio Elqui floodplain and along its banks. In detail, the spatially interpolated SRTM-DEM grid suggests that the bridge spans of about $2.5 \mathrm{~m}$ across the $\approx 100 \mathrm{~m}$ wide flow channel underneath could have accommodated peak flow rates up to about 1800 $\mathrm{m}^{3} \cdot \mathrm{sec}^{-1}$. This estimate is based on Manning's open-channel flow calculator (floodplain slope set at 1\%; Manning's roughness index set at 0.025).

Three of the water reservoirs within the Rio Limari, Rio Elqui and Rio Choapa watersheds are estimated to have accommodated their upstream inflow on May 12, 2017, with the Laguna Reservoir basin receiving only snow, as detailed in Table 2. Two of the reservoirs (La Paloma, Cogoti) were at capacity, and likely overflowed through spillway discharge. The Recoleta reservoir, however, experienced heavy overflows, leading to a partial collapse of its upper wall section (http://www.elmostrador.cl/noticias/multimedia/2017/05/12/video-el-colapso-del -embalse-recoleta-en-ovalle-que-obliga-a-evacuar-zonas-aledanas-al-rio-limari/).

June 2017 Flood Event, Antofagasta Region 
Table 2. Capacity and estimated flow rates at the Coquimbo Region water reservoirs in response to the May 12,2017 storm event.

\begin{tabular}{|c|c|c|c|c|c|c|c|c|c|c|c|c|c|}
\hline \multicolumn{2}{|c|}{ Water Reservoirs } & \multirow{2}{*}{$\begin{array}{l}\text { Long. } \\
\text { Decima }\end{array}$} & \multirow{2}{*}{$\begin{array}{c}\text { Lat. } \\
\text { degrees }\end{array}$} & \multirow{2}{*}{$\begin{array}{c}\text { Elev. } \\
\mathrm{m}\end{array}$} & \multirow{2}{*}{$\begin{array}{c}\begin{array}{c}\text { Reservoir } \\
\text { capacity }\end{array} \\
\text { GL }\end{array}$} & \multirow{2}{*}{$\begin{array}{r}\begin{array}{r}\text { Basin } \\
\text { area }\end{array} \\
\mathrm{km}^{2}\end{array}$} & Rain & \multicolumn{2}{|c|}{$\begin{array}{c}\text { Max. } \\
\text { inflow } \\
\text { (24 hrs) }\end{array}$} & \multicolumn{2}{|c|}{$\begin{array}{l}\text { Water stored prior } \\
\text { to flood event }{ }^{3}\end{array}$} & \multirow{2}{*}{$\begin{array}{c}\begin{array}{c}\text { Inflow on } \\
\text { top of } \\
\text { water }\end{array} \\
\text { Capacity \% }\end{array}$} & \multirow[t]{2}{*}{$\begin{array}{l}\text { Reservoir } \\
\text { functioning }\end{array}$} \\
\hline & & & & & & & $\mathrm{mm}$ & $\mathrm{m}^{3} \cdot \mathrm{sec}^{-1}$ & GL & GL & Capacity $\%$ & & \\
\hline \multirow{2}{*}{ Rio Elqui } & Puclaro & -70.861 & -29.994 & 435 & 210 & 3091 & 37 & 1043 & 116 & 55.0 & 45.0 & 87.9 & Normal \\
\hline & La Laguna $^{1}$ & -70.040 & -30.206 & 3141 & 40.1 & & 0 & 0 & 0 & 0.0 & 58.1 & 58.1 & Normal \\
\hline \multirow{3}{*}{ Rio Limari } & La Paloma & -71.032 & -30.704 & 383 & 750 & 4683 & 35 & 1897 & 164 & 21.9 & 89.1 & 111.0 & At capacity \\
\hline & Recoleta $^{2}$ & -71.093 & -30.496 & 448 & 100 & 1570 & 45 & 818 & 71 & 70.6 & 89.4 & 160.0 & Overflow \\
\hline & Cogoti & -71.091 & -31.026 & 634 & 150 & 1601 & 45 & 834 & 72 & 48.0 & 59.0 & 107.0 & At capacity \\
\hline Rio Choapa & Corrales & -70.914 & -31.911 & 692 & 50.6 & 270 & 18 & 57 & 4.9 & 9.7 & 60.8 & 70.5 & Normal \\
\hline
\end{tabular}

${ }^{1}$ No discharge on account of snow only. ${ }^{2}$ Overflowed May 12, 2017, with partial collapse of an upper section. ${ }^{3}$ Amount of water stored, based on filled versus non-filled SRTM-DEM data collected in 2000.

Another severe rainfall occurred across the Antofagasta region on June 8, 2017. Details about the rainfall distribution of this event and the flow-channel pattern across the hill-shaded watershed areas upslope from Antofagasta are presented in Figure 12 (left). Also shown is an example of how average stream discharge amounts and rates would have varied across the upslope watershed areas assuming no water loss and retention other than what would fill all SRTM-DEM derived $\geq 0.1 \mathrm{ML}$ depressions. No water would have reached the coast if all DEM depressions with as little as $1 \mathrm{~L}$ are also be assumed to be water retaining. In reality, most of the precipitation falling into the south-stretching watershed would be absorbed by the arid floodplain soils, with some of that water entering groundwater reservoirs, and some of that lost through evaporation up to about $3 \mathrm{~mm}$ per day, unless covered by soil and salt crusts [35] [36]. However, seepage and run-off from adjacent upslope areas would easily fill water-receiving depressions within floodplains, as appears to be the case for the coastal floodplain of Antofagasta (Figure 13).

In quantitative terms, the DEM-derived estimates for the event-specific stream discharge rates $\left(y\right.$, in $\left.\mathrm{m}^{3} \cdot \mathrm{sec}^{-1}\right)$ across the Antofagasta watershed areas vary by minimum water-retaining depression volumes $(x$, in GL) as follows:

$$
y=307.9+34.8 \log _{10} x ; R^{2}=0.979 .
$$

For the northern portion, overall depression-based water retention would be small, and would therefore do not depend in $x$ in a major way, i.e.:

$$
y=8.25+0.02 \log _{10} x ; R^{2}=0.10
$$

These equations were obtained through GIS and regression analysis based on systematically determining y by decreasing the water-retention volume threshold per depression $(x)$ from 10 GL to $0.1 \mathrm{ML}$. The largest water retaining volume capacity amounted to $0.28 \mathrm{GL}$ in the northern section at the watershed divide leading eastward towards Salar del Carmen, and 4.22 GL in the southeastern floodplain at the watershed divide along the Pan American Highway, with 
Oficina Rosario located due east.

\section{Further Comments}

The SRTM-DEM derived flow networks not only conform to varying degrees with already mapped river and stream delineations (GIS-DIVA), but also extend these delineations with greater accuracy towards and upwards into the many valleys of the Andean mountain range towards the east. Typically, the channel-to-channel distance conformance between already mapped and the SRTM-DEM derived flow channels is $<100 \mathrm{~m}, 8$ times out of 10 (details not shown). There is also a close correspondence between image and DEM-derived floodplain extent with the threshold for upslope floodplain flow-initiation area set at 400 ha. Terrace heights above the flow-channels with the floodplains can be varied, as these increase with increasing flow accumulation, up to about DTW $=40 \mathrm{~m}$. In addition, within the Coquimbo region, valley soils tend to support vegetation growth up to about DTW $=40 \mathrm{~m}$ within the Coquimbo region.

Through the overlays and processing of precipitation patterns, watershed basins, floodplains, depressions flow channels, roads and railways, it is now possible to estimate:

1) maximum amounts of water transmitted for the upslope watershed areas at any flow-channel point of interest;

2) storm-average maximum run-off rates at any flow-channel location per duration of storm event;

3) approximate flood extent within the lower lying floodplain portions, done by varying the DTW threshold away from the floodplain stream channels;

4) DEM-determined water retention capacities of, e.g., water reservoirs, open-pit mines, quarries, and tailing ponds.

For the context of any particular rainfall event, the information so derived can be used to gauge existing and required infrastructure requirements to withstand actual and projected storm events. Of general importance in this regard is determining the relationship between maximum average potential run-off rates per storm event and the corresponding water retention threshold based on, e.g., depressions and other water-retaining features within watersheds. For this purpose, and to achieve greater accuracies, it is necessary to determine basin-specific relationships between peak and average flow rates per storm duration by way of hydrometric calibrations. Doing so will assist in determining storm- and basin-specific run-off coefficients as they would change by storm event and by antecedent soil, groundwater, and reservoir conditions. For example, the June 2017 run-off coefficient pertaining to the Quebrada La Negra watershed south of Antofagasta was likely near zero, since the water would have mostly been depression-retained through soil and groundwater retention across the far-reaching upslope floodplain complex. Similarly, the March 2015 and May 2017 storm events may or may not have contributed water to Salar del Carmen east of Antofagasta.

Much additional progress in terms of hydro-spatial analyses will likely accrue through processing higher resolution DEMs, either obtained through fusing al- 
ready existing DEM layers (e.g. SRTM, ASTER, elevation contours), and/or using airborne or satellite LiDAR-based bare-earth DEMs [37]. This information would not only enhance the accuracy of the above hydrographic delineations and related flood-exposure assessments but would also assist in quantifying the existing capacity of roads, railways, storm-water systems and other linear corridor infrastructure to withstand major storms. In this regard, road and railway delineations as available per, e.g., Open Street shapefiles generally coincide well with globally available surface images. In contrast, open-source stream and open-water delineations vary in detail and quality, and therefore may or may not follow hydro-topographic expectations in comprehensive detail.

\section{Concluding Remarks}

It is suggested that the DEM-based framework for guiding incoming precipitation through flow channels, floodplains, and depressions could find many practical as well as socio-economic applications to facilitate the planning and management of storm events and water supplies across northern Chile [38]-[43]. The approach as described and illustrated provides a quantitatively informing means to discuss, plan and evaluate hydrological interests and concerns at any location as these change from watershed to watershed, by storm event, and by upslope water-retaining capacities. To this effect, the framework generated results are limited in accuracy by the $30 \mathrm{~m}$ resolution of the SRTM-DEM, which-by way of grid-point interpolation-leads to inadvertent blocking of many flow channels, with the example of the Rio Loa gorge east of Calama in Figure 9 as an extreme case. Hence, the framework can, by itself, only be used to approximate how much storm water may flow and get trapped in real depressions. The amount so trapped is more readily quantified in large and deep depressions than in poorly defined depressions across flat to gently rolling terrain, as demonstrated via Equations (1) and (2) and exemplified in Table 2. In part, some of this difficulty can be addressed through manual if not automated breaching of artificial depressions. For the most part, however, greater accuracy can be achieved using DEMs with point resolution at 1 rather than $30 \mathrm{~m}$. Doing so allows for systematic depression-to-depression water retention evaluations which could then be further evaluated by way of hydrometric and geophysical analyses, calibrations and validations.

\section{Acknowledgements}

This work was supported through Forest Watershed Research Centre activities at the Faculty of Forest and Environmental Management, UNB, Fredericton, New Brunswick, Canada.

\section{Conflicts of Interest}

The authors declare no conflicts of interest regarding the publication of this paper. 


\section{References}

[1] Jordan, T., Riquelme, R., González, G., Herrera, C., Godfrey, L., Steve Colucci, S., León, J.G., Gambo, C., Urrutia, J., Tapia, L., Centella, K. and Ramos, H. (2015) Hydrological and Geomorphological Consequences of the Extreme Precipitation Event of 24-26 March, Chile. XIV Congreso Geologico Chileno, La Serena: AT3 Geología del Cuaternario y Cambio Climático, SIM 12 Los aluviones de Atacama, contexto, causas y efectos, 777-780.

[2] DREF (2015) International Federation of Red Cross and Red Crescent Societies. Flash Floods DREF Emergency Plan of Action (EPoA) No. MDRCL011, Chile.

[3] Davis, W.L., de Pater, I. and McKay, C.P. (2010) Rain Infiltration and Crust Formation in the Extreme Arid Zone of the Atacama Desert, Chile. Planetary and Space Science, 58, 616-622. https://doi.org/10.1016/j.pss.2009.08.011

[4] Wilcox, A.C., Escauriaza, C., Agredano, R., Mignot, E., Zuazo, V., Otárol, S., Castro, L., Gironás, J., Cienfuegos, R. and Mao, L. (2016) An Integrated Analysis of the March 2015 Atacama Floods. Geophysical Research Letters, 43, 8035-8043. https://doi.org/10.1002/2016GL069751

[5] Barrett, B.S., Campos, D.A., Veloso, J.V. and Rondanelli, R. (2016) Extreme Temperature and Precipitation Events in March 2015 in Central and Northern Chile. Journal of Geophysical Research: Atmospheres, 121, 4563-4580. https://doi.org/10.1002/2016JD024835

[6] Izquierdo, T., Abad, M. and Bernárdez, E. (2016) Catastrophic Flooding Caused by a Mudflow in the Urban Area of Copiapó (Atacama Desert, Northern Chile). International Conference on Urban Risks. Lissabon, Portugal, 30 June-2 July 2016, 6 p.

[7] Bahre, C.J. (1979) Destruction of Natural Vegetation of North-Central Chile. University of California Press, Berkeley, 99-109.

[8] Perez-Quezada, J.F., Delpiano, C.A., Snyder, K.A, Johnson, D.A. and Franck, N. (2011) Carbon Pools in an Arid Shrubland in Chile under Natural and Afforested Conditions. Journal of Arid Environments, 75, 29-37. https://doi.org/10.1016/j.jaridenv.2010.08.003

[9] Perez-Quezada, J.F., Bown, H.E., Fuentes, J.P., Alfaro, F.A. and Franck, N. (2012) Effects of Afforestation on Soil Respiration in an Arid Shrubland in Chile. Journal of Arid Environments, 83, 45-53. https://doi.org/10.1016/j.jaridenv.2012.03.015

[10] Suárez, F., Muñoz, J.F., Fernández, B., Dorsaz, J.-M., Hunter, C.K., Karavitis, C.A. and Gironás, J. (2014) Integrated Water Resource Management and Energy Requirements for Water Supply in the Copiapó River Basin, Chile. Water, 6, 2590-2613. https://doi.org/10.3390/w6092590

[11] Andersen, L.E. and Verner, D. (2010) Social Impacts of Climate Change in Chile: A Municipal Level Analysis of the Effects of Recent and Future Climate Change on Human Development and Inequality. Policy Research Working Paper No. 5170, World Bank, Washington DC. https://openknowledge.worldbank.org/handle/10986/19937

[12] BID (Banco Interamericano de Desarrollo) (2014) Guia Metodologica Iniciativa Ciudades Emergentes y Sostenibles. Tercera Edicion. https://publications.iadb.org/handle/11319/8119

[13] Parra, C. and Franks, D. (2011) Monitoring Social Progress in Mining Zones-The Case of Antofagasta and Tarapaca, Chile. First International Seminar Responsibility in Mining, Santiago, Chile.

[14] Weeks, B. (2015) Mine Closure in Chile-Challenges and Changes. Geotechnical 
News, 33, 43-45.

[15] Sanzana, E., Campos, J. and Lopez, A. (2015) Implementation of the Mine Closure Law in Chile: Learned Lessons and Opportunities.

http://www.srk.com/sites/default/files/file/ALopez-ESanzana-JCampos_MineClosur e_2015.pdf

[16] Sartori, A. (2013) National Forests and Climate Change Strategy of Chile: Informal presentation to the Emission Reduction Program under the FCPF Carbon Fund. National Forestry Service (CONAF).

https://www.forestcarbonpartnership.org/sites/fcp/files/2013/june2013/Chilean\%20 ERs\%20Early\%20Idea\%20for\%20the\%20Carbon\%20Fund-\%20English.pdf

[17] NEX-GDDP (2017) NASA Earth Exchange Global Daily Downscaled Projections. https://cds.nccs.nasa.gov/nex-gddp/

[18] GPM (2017) Global Precipitation Measurement NASA. https://www.nasa.gov/mission_pages/GPM/main/index.html

[19] SRTM (2017) Shuttle Rardar Topography Mission. 30-Meter SRTM Elevation Data Downloader. http://dwtkns.com/srtm30m/

[20] Tarboton, D.G. (1997) A New Method for the Determination of Flow Directions and Contributing Areas in Grid Digital Elevation Models. Water Resources Research, 33, 309-319. https://doi.org/10.1029/96WR03137

[21] Murphy, P.N.C., Ogilvie, J., Meng, F.R., White, B., Bhatti, J.S. and Arp, P.A. (2011) Modelling, and Mapping Topographic Variations in Forest Soils at High Resolution: A Case Study. Ecological Modelling, 222, 2314-2332. https://doi.org/10.1016/j.ecolmodel.2011.01.003

[22] White, B., Ogilvie J., Campbell D.M.H., Hiltz D., Gauthier B., Chisholm H.K., Wen H.K., Murphy P.N.C. and Arp, P.A. (2012) Using the Cartographic Depth-to-Water Index to Locate Small Streams and Associated Wet Areas across Landscapes. Canadian Water Resources Journal, 37, 333-347.

[23] Moran, G., Paolini Cuadra, P., Gonzalez, V., Arp, J.-P. and Arp, P.A. (2017) Digitally Mapping the Hydrogeological Context for Community Planning: A Case Study for the Upper Choapa River Watershed in Chile. Journal of Geoscience and Environment Protection, 5, 265-277. https://doi.org/10.4236/gep.2017.53019

[24] Open Street Map (OSM). https://www.openstreetmap.org/user/new

[25] Map Cruzing. http://www.mapcruzin.com/free-chile-country-city-place-gis-shapefiles.htm

[26] DIVA-GIS. http://www.diva-gis.org/gdata

[27] List of Saltpeter Works in Tarapacá and Antofagasta. https://en.wikipedia.org/wiki/List_of_saltpeter_works_in_Tarapac\%C3\%A1_and_A $\underline{\text { ntofagasta }}$

[28] Metals Economics Group. Mine Search-Open Pit, Active Mines in the Americas. https://fusiontables.google.com/DataSource?dsrcid=170038

[29] Hernández, M.F., Herrera, L. and Edwards, S. (2017) Analysis of the Impact of the March 2015 Flood on the Tailings Deposits in the Copiapó Valley. 4th International Seminar on Tailings Management, Santiago, Chile, 12-14 July 2017, 12 p.

[30] Garrido, N., Contreras, J.P., Núñez, G., Ramírez, C., Arenas, M. and Neira, H. (2015) Definición de áreas de evacuación, acopio y reconstrucción post aluviones 03/2015 en las comunas de Chañaral, Salado y Diego de Almagro, III región. Chile. XIV Congreso Geologico Chileno, 781-784. 
[31] Houston, J. (2002) Groundwater Recharge through an Alluvial Fan in the Atacama Desert, Northern Chile: Mechanisms, Magnitudes and Causes. Hydrological Processes, 16, 3019-3035. https://doi.org/10.1002/hyp.1086

[32] Houston, J. (2004) High Resolution Sequence Stratigraphy as a Tool in Hydrogeological Exploration in the Atacama Desert. Quarterly Journal of Engineering Geology and Hydrogeology, 37, 7-17. https://doi.org/10.1144/1470-9236/03-013

[33] Houston, J. (2006) The Great Atacama Flood of 2001 and Its Implications for Andean Hydrology. Hydrological Processes, 20, 591-610. https://doi.org/10.1002/hyp.5926

[34] Houston, J. and Hartley, A.J. (2003) The Central Andean West-Slope Rainshadow and Its Potential Contribution to the Origin of Hyper-Aridity in the Atacama Desert. International Journal of Climatology, 23, 1453-1464. https://doi.org/10.1002/joc.938

[35] Kampf, S.K., Tyler, S.W., Ortiz, C., Muñoz, J.F. and Adkins, P.L. (2005) Evaporation and Land Surface Energy Budget at the Salar de Atacama, Northern Chile. Journal of Hydrology, 310, 236-252. https://doi.org/10.1016/j.jhydrol.2005.01.005

[36] Yang, J.-L., Zhang, G.-L., Yan, F., Yang, R.-M., Yi, C., Li, D.C., Zhao, Y.-G. and Liu, F. (2016) Controlling Effects of Surface Crusts on Water Infiltration in an Arid Desert area of Northwest China. Journal of Soils and Sediments, 16, 2408-2418. https://doi.org/10.1007/s11368-016-1436-Z

[37] Furze, S., Ogilvie, J. and Arp, P.A. (2017) Fusing Digital Elevation Models to Improve Hydrological Interpretations. Journal of Geographic Information System, 9, 558-575. https://doi.org/10.4236/jgis.2017.95035

[38] Valentin, C. (2005) Surface Crusts of Semi-Arid Sandy Soils: Types, Functions and Management. Session 4: Physical Properties of Tropical Sandy Soils. Management of Tropical Sandy Soils for Sustainable Agriculture, Khon Kaen, Thailand, 182-188.

[39] Vargas, G., Ortlieb, L. and Rutllant, J. (2000) Aluviones históricos en Antofagasta y su relación con eventos El Niño/Oscilación del Sur. Revista geológica de Chile, 27, 157-176.

[40] Zavala, H. and Trigos H. (2008) Hidrología de la cuenca del Valle de Elqui. In: Cepeda, P.J., Ed., Los Sistemas Naturales de la Cuenca del Río Elqui (Región de Coquimbo, Chile): Vulnerabilidad y Cambio del Clima, Ediciones Universidad de La Serena, La Serena, Chile, 66-164. http://www.parc.ca/mcri/pdfs/books/cepeda/3.pdf

[41] Zuzino, H.Z., Agüero, H.T., Antequera, I.M. and Rojas, E.M. (2008) Hidrilogia Cuenca Rio Elqui. MCRI Project: Institutional Adapatations to Climate Change: Comparative Study of Dryland River Basins in Canada and Chile. http://www.parc.ca/mcri/pdfs/Hidrologia.pdf

[42] Chile. Emergencia Hidro-Meteorológica en el Norte. Reporte de Situación No. 3 de la Oficina del Coordinador Residente, 311-318.

[43] Diaz, I.S. (2015) Diagnóstico Preliminar. Adaptación ambiental y salud pública post aluvión: Chañaral y Atacama. Pontificicia Universidad Católica de Chile, Santiago, $23 \mathrm{p}$. http://www.cedeus.cl/wp-content/uploads/2015/11/Informe-Cha\%C3\%B1aral.pdf 